\title{
Role of CSR in Corporate Long Term Survival and Long Term Sustainable Development - A Research on Nalco, Odisha
}

\author{
Santanu Kumar Das
}

\begin{abstract}
CSR is a business strategy that works in a world where brand value and reputation are increasingly seen as an organization's most valuable asset. It can build the loyalty and trust that ensure a bright sustainable future. In our complicated, international society, partnerships have become grade by grade apparent. these agencies aren't made a decision on their effects but on their conduct as properly. therefore CSR have to have become a essential piece of each a part of commercial enterprise lifestyles and this acquires improvement budgetary execution, builds profitability, higher danger and emergency the board, increased specialist obligation, extraordinary individuals of the own family with government and networks, upgraded brand clearly well worth and notoriety this brings to lengthy haul staying power and affordable development to the corporation. primarily based on these, this investigation is under taken to recognise whether or now not CSR exercising of Nalco has affected on the long haul staying energy and supportable development of the company, the exam implemented organized ballot and assembly method to collect the data from the respondents. The exam has applied chi rectangular method to check theories and both the non-obligatory idea are mentioned and check uncovers that additives of CSR exercise of the agency effects on lengthy haul patience and maintainable improvement of the enterprise. as a result, there may be a requirement for NALCO prepared in Odisha to improve the CSR workout and revealing it usually.
\end{abstract}

Keywords-Survival, Sustainable development, Communities, Integral

\section{INTRODUCTION}

Corporate Social responsibility (CSR) Implies a precept that says that an detail whether or now not it's far government, non-public businesses or open affiliation has an duty to society. CSR is an idea that diminishes charges and dangers, builds the logo well worth and notoriety, adequacy and the proficiency of representatives, improves straightforwardness, and lucidity within the place of job of the economic business enterprise house and upgrades supportable development of corporate.

As indicated by discover with the useful resource of the exchange association enterprise for social obligation, corporations document brazenly on their CSR movement to satisfy the desires of partners and different intrigued people, as an instance, employees, customers, customers, organizations, traders, law imprints and controllers who are requesting that corporations be accountable for their very private presentation, however in addition for the effect of

Revised Manuscript Received on 14 August, 2019.

Dr.Santanu Kumar Das, Assistant Professor, P.G. Department of Business Administration, Kalam Institute of Technology, Berhampur, Odisha, India; (E-Mail: santanu.das.kumar@gmail.com) their items, the exhibition of their maintain community and the prosperity in their own exhibition, however furthermore for the effect in their very very own presentation, but similarly for the impact in their devices and the exhibition in their representatives.

In India, the concept of CSR is administered thru circumstance a hundred thirty five of the organizations Act, 2013, which was exceeded through the 2 homes of the Parliament, and had gotten the consent of the President of India on 29th August 2013. The CSR preparations in the Act is relevant to corporations with a yearly turnover of INR 1, 000/ - crore and the sky's the restrict from there, or a whole property of INR 500/ - crore and that is handiest the top of the iceberg, or a internet gain of INR 5 crore and the sky's the restrict from there. the new policies, with a purpose to be pertinent from the economic year 2014-15 onwards, furthermore anticipate corporations to set-up a CSR advisory institution comprising of their board individuals, such as in any event one loose executive. The Act urges corporations to spend at any price $2 \%$ in their everyday net benefit inside the past 3 years on CSR physical activities. The provider's draft leads, that have been installation for open statement, symbolize net advantage because the gain earlier than price in keeping with the books of facts, barring benefits rising from branches out of doors India.

\section{LITERATURE REVIEW}

Prabjot Kaur made an research on, "corporate Social duty: gift scenario in India", He expresses that, India's growing CSR device and its capacity great and shortcoming likewise he proceeded with the corporate notoriety is a massive essential aid that gives to employer-stage determined productiveness and insists that solid notoriety is attached with unequalled money associated execution and supportable improvement.

Ramendra Singh and Sharad Agarwal made an research on, "corporate Social responsibility for social impact: manner to deal with measure social effect using CSR effect record". They expresses that, maximum agencies in India draw in with close by networks close to their territories of responsibilities, and the recipients of CSR sports activities are usually the community population, these companies need to try and create adaptable models of CSR that can be stretched out the us of a over the usage of community NGO's in every land place, a supportive asset yet requiring little to no effort, flexible models can be beneficial in developing the financial effect of CSR sporting occasions of the corporate. 


\section{ROLE OF CSR IN CORPORATE LONG TERM SURVIVAL AND LONG TERM SUSTAINABLE DEVELOPMENT - A RESEARCH ON NALCO, ODISHA}

Rajeev Prabhakar and Sonam Mishra made an examination on, "company Social duty in Indian association: a reflection", currently an afternoon's companions are addressing extra on CSR sports of the corporations nowadays, they're attempting out the groups. It has gotten simple to consolidate it for partners.

Venugopal, R made an exam on, "company Social responsibility and the protection area". He expresses that, it is not enough if an organisation makes a benefit, if must likewise expect a essential task within the existence of the network. The directorate of the organisation wishes to watch the necessities in their quick community and make strides in improving them in an cheaper manner, on this manner shopping for the appellation of a 'high-quality corporate resident'. Indian safety net companies have to this point related to each immediately truly as backhanded CSR physical games. apart from being protected via implication inside the activation of belongings for the improvement of countrywide economy, they may be moreover straightforwardly associated with severa socially conscious causes. america, insurance corporations are the widespread shoppers for CSR. they've given $\$ 147 \mathrm{mn}$, moreover unique biggest companies they placed resources into subsidizing the shape of avenue, schools and other open ventures. They likewise deliver coins-go with the flow to discover trends via pastimes in corporate values and securities. Any organization that requirements to recall itself a excellent corporate resident' need to spend in any occasion $1 \%$ of its in advance years pre-charge benefit for CSR features.

Nitin Kumar made an investigation on, "corporate Social duty: An examination of effect and issues in India". He expresses, that, CSR has developed from being regarded as hindering to an business company's gainfulness, to being considered as thru one way or some other profiting the organisation all in all, in any event over the lengthy haul. The problems confronting CSR activities in India are absence of community investment in CSR sports, requirements for limit running of the network nonadministrative establishments, problems straightforwardness, non-accessibility of inexperienced non-legislative institutions, and so on. in the endured years company commercial agency houses have drastically protected towards cultural obligations. agencies have commenced to understand the importance of CSR and beginning the approach closer to it. This exertion will likewise convince exclusive company house to sign up for the affiliation and count on a successful manner in tending to issues, for example, access to training, human offerings and industrial agency open doors for infinite people in India via their innovative CSR rehearses.

Ananda Das Gupta made an exam on, "Executing company Social duty in India: problems and the beyond". He expresses that, the control of India started out corporate responsibility for environmental protection (CREP) commenced by means of the Indian government as of overdue in 2003, set rules of non-compulsory necessities for 17 dirtying businesses. corporate social responsibility is essentially some other business organisation device to reduce speculation risks and lift advantages with the aid of taking all of the key stake $\neg$ holders into fact. in the developing point of view CSR orders upon organizations to

have a look at advantages in conjunctions with social flourishing. company offers weight on them as the companions, in a commercial employer aren't in reality the consumers, reasonable development and financial supportability, corporate advantages to be broke down associated with social success. alongside those lines, ethical employer is grade by grade a key want, growing pattern on the regular seeing that. In a ethical agency, the primary receive as actual with is on social developments and commercial agency is led in consonance with more giant social traits and the partner's long haul intrigue.

\section{OBJECTIVES OF THE STUDY}

* To analyze the CSR factors this influenced on the long term survival and sustainable development of the National Aluminium Company Limited (NALCO)

* To give some suitable suggestions for accelerating CSR initiatives in NALCO.

\section{RESEARCH METHODOLOGY}

\subsection{Type of research}

This examination is an experimental in nature, directed to know how CSR practice can become apparatus for endurance and reasonable improvement of the corporate segment.

\subsection{Scope of the Study}

The study conducted to know about the perception of employees about the CSR practices in the corporate and to analyze how it become tool for survival and sustainable development of corporate. The study only restricted to National Aluminium Company Limited (NALCO) is a public sector enterprise of the Ministry of Mines, Government of India. NALCO is a manufacturer and distributor of aluminum products in Odisha.

\subsection{Sample Design:}

* Sampling Method: Convenient sampling method is used to select the sample.

* Sample Size: The sample size of this study is 60 respondents.

* Sample Frame: Employees of NALCO.

\subsection{Hypothesis}

H0: CSR is not a tool for Corporate Long term Survival and Long Term Sustainable Development.

H1: CSR is a tool for Corporate Long term Survival and Long Term Sustainable Development.

\section{ANALYSIS AND INTERPRETATION}

\section{Discussion and Conclusion:}

Table no - 5.1: Profile of respondents

\begin{tabular}{|l|c|c|}
\hline \multicolumn{3}{|c|}{ Gender } \\
\hline & No. of Respondents & Percentage (\%) \\
\hline Male & 30 & 50 \\
\hline Female & 30 & 50 \\
\hline
\end{tabular}




\begin{tabular}{|l|c|c|}
\hline Total & 60 & $100 \%$ \\
\hline Age Group & 20 & 33 \\
\hline $18-25$ & 19 & 32 \\
\hline $26-35$ & 7 & 12 \\
\hline $36-50$ & 14 & 23 \\
\hline 50 and above & 60 & $100 \%$ \\
\hline Total &
\end{tabular}

\subsection{Hypothesis Test:}

The outlined hypothesis of the study is tested with the help of chi square.

\subsection{Sources of Data}

The examination has carried out each essential and optionally available facts.

The essential statistics of this examination has accumulated from respondents (representatives of NALCO) via prepared meeting and survey approach.

The non-obligatory statistics for this research has accrued from disbursed resources, for instance, articles, exclusive agency CSR reviews, books, diaries and periodicals.

\begin{tabular}{|l|c|c|}
\hline Work Experience & 39 & 65 \\
\hline $0-10$ years & 11 & 18 \\
\hline 11-20 years & 7 & 12 \\
\hline 21-30 years & 3 & 5 \\
\hline Above 31 years & 60 & $100 \%$ \\
\hline Total & 2 & 3 \\
\hline Annual Income & 8 & 13 \\
\hline Below Rs. 50,000 & 2 & 3 \\
\hline Rs. 50,001 to Rs. 1,00,000 & 48 & 80 \\
\hline Rs. 1,00,001 to Rs. 2,00,000 & 60 & $100 \%$ \\
\hline Rs. 2,00,001 and Above & 9 & 15 \\
\hline Total & 21 & 35 \\
\hline Education level & 26 & 43 \\
\hline Below PUC & 4 & 7 \\
\hline UG & 60 & $100 \%$ \\
\hline PG
\end{tabular}

(Source: Primary data)

The above table shows that, there can be an identical quantity of male and woman respondents are taken for this investigation and lion's percentage of them has a place with 18 to 35 age collecting. each one of the respondents are taught and big part of them completed UG and PG and their each 12 months revenue is more than Rs 2, 00, 000. Lion's proportion of the representatives working experience is zero to 20 years.

Table no 5.2: Respondents awareness about CSR activity

\begin{tabular}{|c|c|c|}
\hline Awareness & No. of Respondents & Percentage (\%) \\
\hline Yes & 60 & 100 \\
\hline
\end{tabular}

\begin{tabular}{|c|c|c|}
\hline No & 0 & 0 \\
\hline Total & 60 & 100 \\
\hline
\end{tabular}

From the above table it clears that, all respondents are aware about CSR activities of the NALCO.

Table no 5.3: Means through which Respondents came to know about NALCO's CSR practice

\begin{tabular}{|l|c|c|}
\hline \multicolumn{1}{|c|}{ Means } & $\begin{array}{c}\text { No. of } \\
\text { Respondents }\end{array}$ & $\begin{array}{c}\text { Percentage } \\
(\%)\end{array}$ \\
\hline Friends, Relatives & 0 & 0 \\
\hline Media & 0 & 0 \\
\hline Through company report & 0 & 0 \\
\hline Website of the NALCO & 60 & 100 \\
\hline Total & 60 & 100 \\
\hline
\end{tabular}

\section{(Source: Primary data)}

From the above table unmistakably, greater part of the respondents know about CSR rehearses through organization's site.

Table no 5.4: NALCO community Development initiatives under CSR practice

\begin{tabular}{|l|l|l|}
\hline Community Development & $\begin{array}{c}\text { No. of } \\
\text { Respondents }\end{array}$ & $\begin{array}{c}\text { Percentage } \\
(\%)\end{array}$ \\
\hline Local heritage & 31 & 52 \\
\hline Disability & 1 & 2 \\
\hline Conservation & 6 & 10 \\
\hline Youth development & 7 & 12 \\
\hline Underprivileged & 3 & 5 \\
\hline Poverty alleviation & 4 & 7 \\
\hline Sports & 5 & 8 \\
\hline Culture & 2 & 3 \\
\hline Others & 1 & 2 \\
\hline Total & 60 & 100 \\
\hline
\end{tabular}

(Source: Primary data)

The above desk shows that, beneath CSR the enterprise organization made more ventures on development of community legacy and they have centered a lot much less on one in every of a kind areas.

Table no 5.5: Respondents opinion towards CSR as a tool for corporate long term survival and sustainable growth

\begin{tabular}{|l|c|l|}
\hline $\begin{array}{l}\text { Capacity building \& } \\
\text { Sustainable development }\end{array}$ & $\begin{array}{l}\text { No. of } \\
\text { Respondents }\end{array}$ & $\begin{array}{l}\text { Percentage } \\
(\%)\end{array}$ \\
\hline Strongly agree & 38 & 63 \\
\hline Agree & 19 & 32 \\
\hline Neutral & 3 & 5 \\
\hline Disagree & 0 & 0 \\
\hline Strongly disagree & 0 & 0 \\
\hline Total & 60 & 100 \\
\hline
\end{tabular}




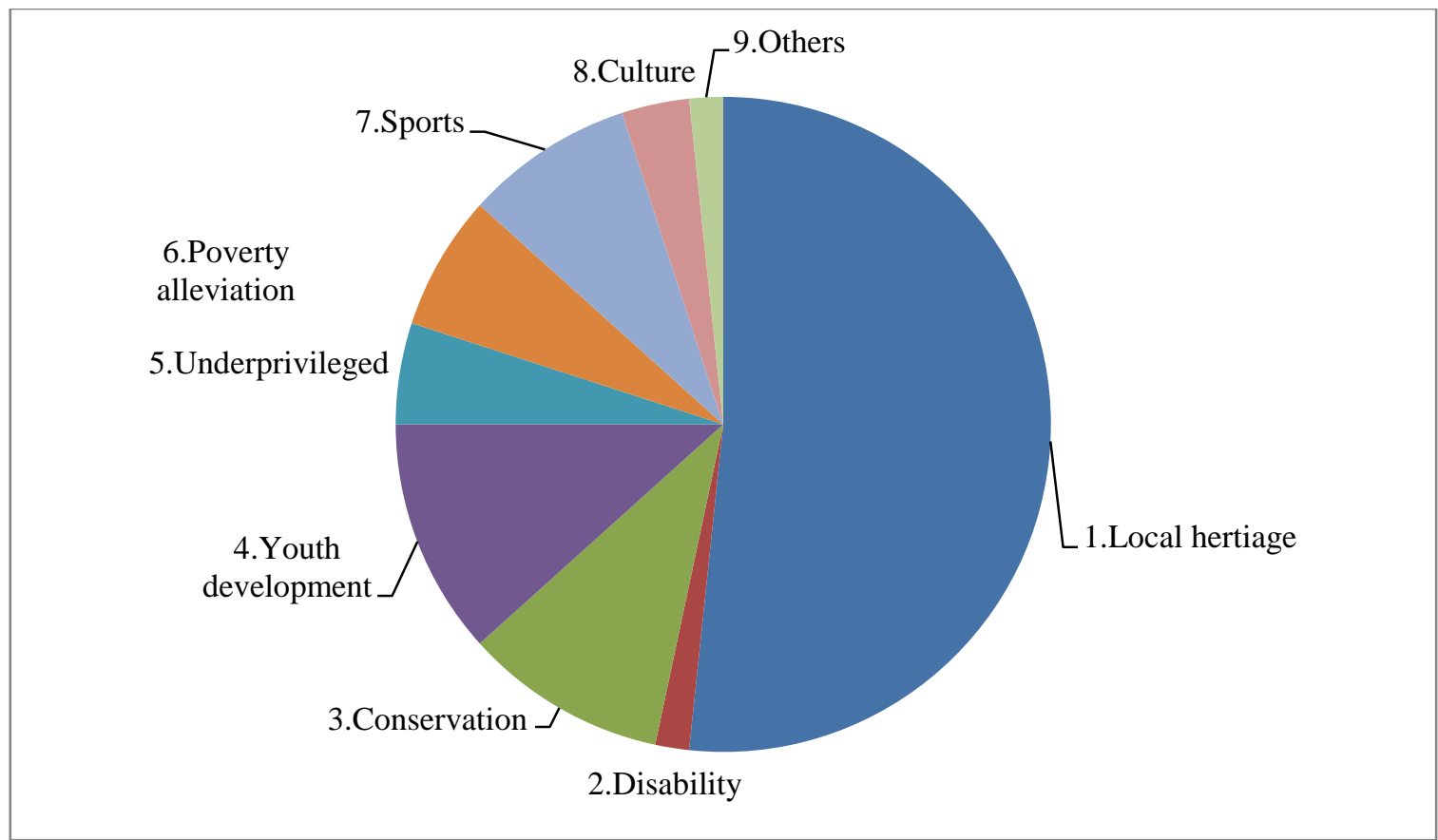

Figure - 5.1: NALCO community development initiatives under CSR practice

The above table shows that, majority of the respondents strongly agreed that CSR is a device for the company long time survival and sustainable boom.

Table no 5.6: Factors influenced on the long term survival of the organization through CSR practice

\begin{tabular}{|l|c|c|c|c|c|c|}
\hline Variables & SA & A & N & D & SD & Total \\
\hline Meets clients requirements improves relationship & 33 & 21 & 5 & 1 & 0 & 60 \\
\hline Improves stakeholders and management relation ships & 18 & 28 & 9 & 2 & 3 & 60 \\
\hline Improves economic performance & 15 & 32 & 9 & 2 & 2 & 60 \\
\hline Motivates top management & 20 & 26 & 13 & 1 & 0 & 60 \\
\hline Improves marketing, public relations and corporate image & 19 & 24 & 12 & 2 & 3 & 60 \\
\hline Gaines a competitive advantage & 18 & 21 & 17 & 3 & 1 & 60 \\
\hline Increases efficiency and productivity & 18 & 27 & 12 & 2 & 1 & 60 \\
\hline Improves relationship with financial institutions & 18 & 19 & 18 & 4 & 1 & 60 \\
\hline $\begin{array}{l}\text { Achieve relevant accreditation (environmental, quality, health } \\
\text { and security etc) }\end{array}$ & 23 & 20 & 16 & 1 & 0 & 60 \\
\hline
\end{tabular}

(Source: Primary data)

(SA-Strongly agree, A-Agree, N-Neutral, D-Disagree, SD-Strongly disagree)

H0: CSR is not a tool for Corporate Long term Survival

H1: CSR is a tool for Corporate Long term Survival

$$
X^{2}=\sum_{i=1}^{n} \frac{(o i-E i)^{2}}{E_{i}}
$$

\begin{tabular}{|c|c|c|c|}
\hline Table value @ 1\% level of significance & $\begin{array}{c}\text { Table value @ 5\% level of } \\
\text { significance }\end{array}$ & Computed value & Degree of freedom \\
\hline 32 & 26.30 & 41.938 & 32 \\
\hline
\end{tabular}

The table an incentive for $1 \%$ degree of criticalness is 32 . The desk an incentive for five \% diploma of centrality is 26.30. The figured well worth is forty one.938. considering the fact that, the figured truely really worth is more than each the table characteristics. So non-obligatory hypothesis is mentioned and its very last outcomes demonstrates that all of the components are affected at the long haul endurance of the affiliation through CSR workout. 


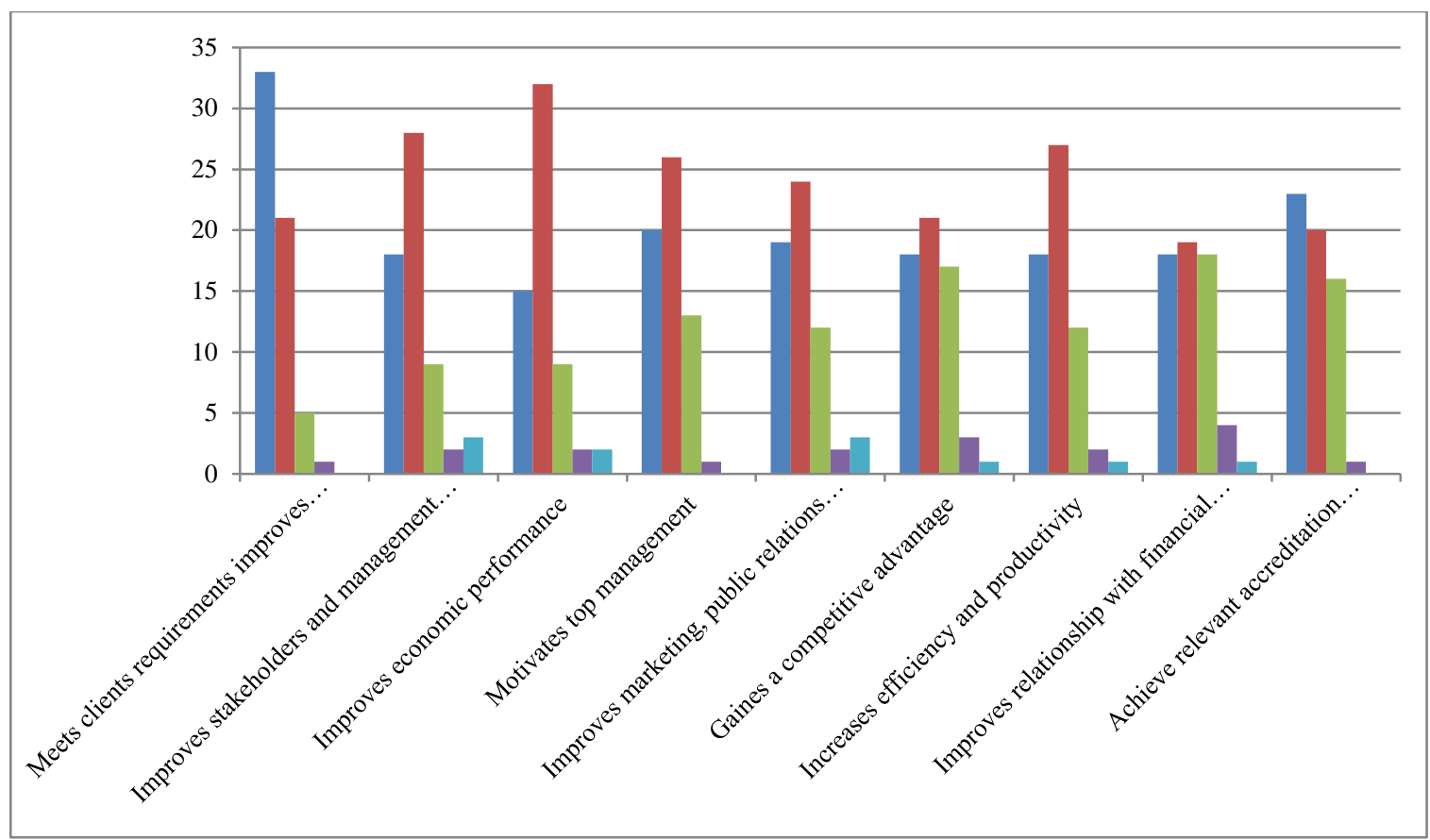

Figure - 5.2: Factors influence on the survival of the organization through CSR

Table no- 5.7: Respondents opinion towards sustainable development through CSR practice

\begin{tabular}{|l|c|c|c|c|c|c|}
\hline Variables & SA & A & N & DA & SDA & Total \\
\hline Customer satisfaction and awareness & 37 & 18 & 5 & 0 & 0 & 60 \\
\hline Quality product at an affordable rate & 28 & 26 & 5 & 1 & 0 & 60 \\
\hline Retention of employees & 23 & 22 & 14 & 0 & 1 & 60 \\
\hline Motivate and improve employees morale & 23 & 29 & 7 & 1 & 0 & 60 \\
\hline Corporate donarship and volunteerism & 14 & 27 & 13 & 5 & 1 & 60 \\
\hline Support sod at integration & 17 & 27 & 12 & 2 & 2 & 60 \\
\hline Developing employment and infrastructure & 20 & 26 & 7 & 7 & 0 & 60 \\
\hline Greater efficiency and less waste & 14 & 27 & 12 & 6 & 1 & 60 \\
\hline Attract green and ethical investment & 21 & 25 & 11 & 1 & 2 & 60 \\
\hline Environmental friendly products, services & 18 & 30 & 10 & 0 & 2 & 60 \\
\hline Compliance with regulations and standards & 25 & 28 & 4 & 3 & 0 & 60 \\
\hline Protection of natural resources & 28 & 22 & 9 & 1 & 0 & 60 \\
\hline
\end{tabular}

\section{(SA-Strongly agree, A-Agree, N-Neutral, D-Disagree, SD-Strongly disagree)}

H0: CSR is not a tool for Corporate Sustainable Growth

H2: CSR is a tool for Corporate Sustainable Growth

$$
X^{2}=\sum_{i=1}^{n} \frac{(o i-E i)^{2}}{E_{i}}
$$

\begin{tabular}{|c|c|c|c|}
\hline $\begin{array}{c}\text { Table value @ 1\% level of } \\
\text { significance }\end{array}$ & $\begin{array}{c}\text { Table value @ 5\% level of } \\
\text { significance }\end{array}$ & Computed value & Degree of freedom \\
\hline 32 & 26.30 & 56.274 & 44 \\
\hline
\end{tabular}
the desk characteristics, finally, optionally to be had

The table an incentive for $1 \%$ level of hugeness is 32 . The desk an incentive for $5 \%$ degree of criticalness is 26.30 . The registered worth is fifty six.274. considering the fact that, the processed absolutely well worth is extra than each speculation is stated and its outcome demonstrates that each one of the variables are affected on the maintainable development of the affiliation through CSR. 


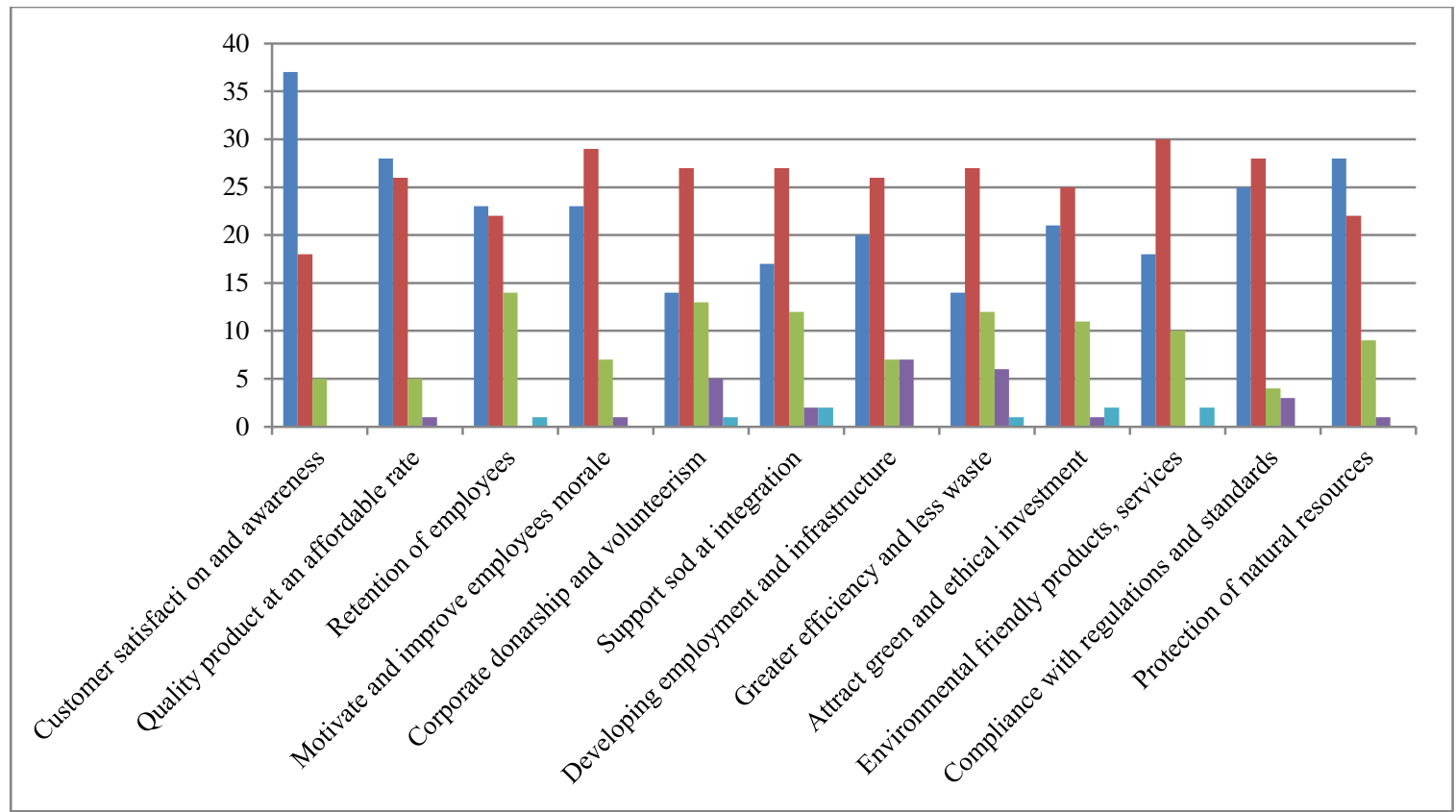

Figure- 5.3: Respondents opinion about sustainable development through CSR practice

Table no- 5.8: Environmental Protection Programmes Undertaken by the Organization in CSR Practice

\begin{tabular}{|l|c|c|}
\hline \multicolumn{1}{|c|}{ Measures } & $\begin{array}{c}\text { No. of } \\
\text { Respondents }\end{array}$ & $\begin{array}{c}\text { Percent } \\
\text { age (\%) }\end{array}$ \\
\hline Energy saving programmes & $\mathbf{3 8}$ & $\mathbf{3 0}$ \\
\hline $\begin{array}{l}\text { Life cycle assessment } \\
\text { processes }\end{array}$ & $\mathbf{1 1}$ & $\mathbf{9}$ \\
\hline Waste recycling of & $\mathbf{1 1}$ & $\mathbf{2 5}$ \\
\hline $\begin{array}{l}\text { Management } \\
\text { environmental system }\end{array}$ & $\mathbf{1 2}$ & $\mathbf{9}$ \\
\hline Mobility Management of & $\mathbf{1 1}$ & $\mathbf{9}$ \\
\hline Use of renewable resources & & $\mathbf{9}$ \\
\hline $\begin{array}{l}\text { Development } \\
\text { environmental } \\
\text { Products }\end{array}$ & $\mathbf{1 2 7}$ & $\mathbf{1 0 0}$ \\
\hline Total & & \\
\hline
\end{tabular}

(Source: Primary data)

Under CSR practice the association has underneath taken some ecological security programs. Among 127 generally speaking reactions, lion's share of the respondents opined that, power sparing projects and waste reusing are the measures which may be significantly attempted through the venture and for unwinding of the projects they concentrated less.

Table no- 5.9: Problems faced by employees from improper management of CSR practices

\begin{tabular}{|l|c|c|}
\hline \multicolumn{1}{|c|}{ Problems } & $\begin{array}{c}\text { No. of } \\
\text { Respondents }\end{array}$ & $\begin{array}{c}\text { Percentage } \\
(\%)\end{array}$ \\
\hline Less employee safety & 24 & 40 \\
\hline Women rights not given & 8 & 13 \\
\hline $\begin{array}{l}\text { Irregular work load on } \\
\text { employees }\end{array}$ & 25 & 42 \\
\hline Unfair pay & 3 & 5 \\
\hline More child labour & - & - \\
\hline Total & 60 & 100 \\
\hline
\end{tabular}

(Source: Primary data)
This shows that, by improper management of CSR practice the organization facing certain problems internally. Among the above problems less safety for employees and irregular load from the top management are the major problems employees are facing

Table no - 5.10: Reasons for Improper Management of CSR Practice

\begin{tabular}{|l|c|c|}
\hline \multicolumn{1}{|c|}{ Obstacles } & $\begin{array}{c}\text { No. of } \\
\text { Responses }\end{array}$ & $\begin{array}{c}\text { Percentage } \\
(\mathbf{\%})\end{array}$ \\
\hline Lack of human resources & 15 & 13 \\
\hline Lack of funds & 32 & 28 \\
\hline Lack of time & 29 & 25 \\
\hline Lack of specific legislation on & 8 & 7 \\
\hline Lack of employee motivation & 9 & 8 \\
\hline Lack of knowledge from top & 5 & 11 \\
\hline Lack of support not & 5 & 4 \\
\hline Business benefits & $\mathbf{1 1 6}$ & $\mathbf{1 0 0}$ \\
\hline Total
\end{tabular}

This shows that, there are number of reasons which influenced on the improper management of CSR practices in the organizations. Among those, lack of fund and time are the major constraints.

\section{FINDINGS}

- all the representatives in NALCO realize approximately the CSR exercising led of their institutions and dominant part of them comprehend approximately it via the business enterprise internet site.

- NALCO continually designating and the making plans sum for CSR utilization and it's miles above Rs 1, 50, 000 PA. 
- NALCO continuously giving assets to CSR within the techniques for cash and in type.

- NALCO positioned greater in nearby legacy and kids advancement as a piece of its locale speculation sports under CSR exercise and plenty less focused on other community improvement bodily video games.

- NALCO acquired the shopping for association/fine gauges and they direct the employee's fulfillment assessment, typically as a chunk of CSR exercise.

- all the representatives inside the NALCO concurred that "CSR is an instrument for long haul patience and persisted improvement".

- CSR document isn't always set up with the aid of the NALCO however some records is unveiled in web sites.

- worker safety and sporadic artwork is the acute issues as of overdue looked with the aid of way of the affiliation by using irrelevant control of CSR exercise.

- The ability benefits of the economic organization and nature of the blessings of CSR for an affiliation depending upon the idea of the undertaking, as a consequence it is hard to evaluate.

- Majority of humans of the affiliation concur that there's a connections amongst gain and CSR physical games of the affiliation

- enterprise embraces energy reserve fee range, squander reusing measures to lower herbal effect.

- The greatest obstacle appeared via the affiliation to rehearse CSR is absence of HR, absence of assets and time.

- Social duties of commercial enterprise have made a advanced photo and generosity to the enterprise. with a view to becomes an instrumental in pulling in clients, representatives and furthermore speculators, which conveys the affiliation for lengthy haul potential development.

- effects of first speculation: H1: CSR is a device for corporate long term Survival

- CSR meets consumer's requirements to enhance the connection

- CSR improves companions and makes terrific affiliation with the administration

- It likewise improves monetary execution of the organization

- Motivates pinnacle management to perform wearing sports adequately

- It improves agencies promoting, open connections and moreover makes brilliant organisation photograph

- via it is viable for the commercial enterprise company to growth top hand

- It improves association with economic foundations

- It has moreover recommended important accreditations, for instance, herbal, nice, wellbeing and protection and so on.

- results of $2 \mathrm{~d}$ concept: H2: CSR is an system for company possible development

- CSR facilitates in possible improvement as it offers consumer loyalty and mindfulness

- CSR serves to clients to get quality devices at an low priced fee and it holds the clients

- It evokes employees to enhance self belief and keep with the corporation

- It builds donarship and volunteerism and moreover underpins for social aggregate

- It pulls in businesses for inexperienced and moral hypothesis. It motives the organizations to create herbal nicely disposed devices and administrations

- CSR likewise allows in safety of everyday assets.

\section{SUGGESTIONS}

- CSR is needed for figure corporate for their long haul staying strength and supportable development. So the corporate need to rehearse CSR constantly. everybody in the association wishes to understand their very own method in advancing CSR and groups must likewise need to provide more widespread expert development bodily video games.

- schooling, gatherings and publications ought to be sorted out to disperse and convey new gaining knowledge of and information about CSR exercise.

- A stable budgetary assist might extend CSR workout and research identified with separate affiliation could beautify the associations dedication.

- government guidelines that are helping in the direction of this path ought to pull in extra reaction from associations. this may likewise prompt benchmark for CSR exercises.

- employer want to distribute the CSR file robotically.

- enterprise want to consist of their CSR bodily sports which deliver together lengthy haul institutions with partners which would prompt creating a strong picture and brand person.

- organizations need to set a gadget of carrying activities to be taken up in a consortium to deal with important ecological issues. it'd likewise deliver a risk to gain from every different.

- Accounting our bodies need to make CSR bookkeeping preferred which keeps up uniform technique for CSR bookkeeping.

- CSR sports activities enhance company social purpose under territories of typical benefit commitment. Human asset dedication, open determination, ecological determination, item or control commitment.

- With the straightforwardness of social price and advantages in coins terms. anyhow, it is fundamental as a way to decorate the heads of detailing as regards to dynamic monetary scenario.

- The difficulties are currently the adaptable modules for the CSR to be performed, order to its endeavor plan with the company worldwide.

- groups ought to direct occasional survey of the CSR physical games as a way to be led thru a particular association.

- pinnacle the board assist, comfort to CSR motion is essential through giving facts approximately reserve and distinct assets. 


\section{ROLE OF CSR IN CORPORATE LONG TERM SURVIVAL AND LONG TERM SUSTAINABLE DEVELOPMENT - A RESEARCH ON NALCO, ODISHA}

- corporation want to find out a way to decrease ecological impact they have to pursue strength reserve budget, squander reusing, utilization of inexhaustible property, improvement of herbal neighborly item, versatility the board and so forth.

- through receiving suitable innovation or foundation, affiliation can electricity over the sporadic paintings, and might beautify youngsters work, girls rights, representative safety, and affordable repayment problems.

- in the era approach affiliation should enhance fitness measures to humans. eight. cease

The CSR workout has really become an equipment for agency lengthy haul staying power and continued development of the affiliation. The exam uncovers that, irrelevant management of CSR triggered the NALCO to confront troubles, as an instance, employee security, girls rights and unpredictable closing challenge accessible for representative. the ones problems may be canceled through the right administration of CSR exercise for the reason that each top notch work it in fact valued by means of manner of every body so the CSR thru the affiliation it draws inside the human beings for compelling walking requirements like increasing business aggressiveness and marketplace get to, making investor nicely well worth and little by little access to capital, upgrading brand notoriety through doable confirmation on ethical acquiring choices, enhancing consultant enlistment, safety and execution via appealing professionals, improving employer related aptitudes and bringing issues to mild on the challenge's pledge to paintings achievement and super working situations, supply well-being measures to people, supply equal rights to girls, risk the executives and cost sparing sports, enhancing object nice, improving store community the board, upgrading operational effectiveness, fortifying stake $\neg$ holder connections, enhancing network advancement and guide, and showing aware authority, rehearsing corporate Social responsibility in numerous areas of commercial business enterprise this can assist for the agency lengthy haul persistence and maintainable development.

\section{REFERENCES}

1. Ananda Das Gupta, 2014, implementing corporate Social obligation in India: issues and the past.

2. Georgina nunez, (July 2008), "Advancing CSR in little and medium ventures within the carebbean: assessment effects", ECLAC workplace in Washington.

3. Mahammad ghouse, S. what's extra, Zakker bhasha, S. "job of company Social duty in countrywide Reinforcement" IOSR journal of Humanities and Social technology, Pp 15 - 23.

4. Nithin Kumar (might also 2014), "corporate Social obligation: An exam of effect and difficulties in India", Abhinav international month to month Refereed journal of research in the executives and innovation, Vol. three, difficulty five Pp. 97-104.

5. Prabjot Kaur (June 2013) corporate Social responsibility: present state of affairs In India, magazine of trade and control concept, Vol. 6-three, Pp. 496-511.

6. coverage on company Social duty, (June 2015), Board CSR constitution and approach.
7. Rajeev Prabhakar and SonamMishra, (June 2013), A take a look at of corporate Social duty in Indian enterprise: An-Introspection, intending of 21st global business research conference, Rhyrson university, Toronto, Canada, ISBN: 978-1-922069-25-2.

8. Ramendra Singh and Sharad Agarwal, June 2013 , corporate Social responsibility for Social impact: method to measure social effect using CSR impact Index, Indian establishment of the board Calcutta, WPS No. 729.

9. studies tablet: The reputation of company Social duty in India - A observe, (might also 2005), Environmental management middle, Pp 1 - 12.

10. rich Gautam and Anju Singh, 2010, company Social duty Practices in India: An studies of top 500 businesses, global commercial enterprise and management studies: An global magazine, Vol. 2, No. 1, Pp. 41-fifty six.

11. Sanjay Pradhan, Akhilesh Ranjan, 2010, corporate Social duty in Rural improvement sector: Evidences from India, faculty of Doctoral research ecu Union diary, problem 2, Pp. 139 - 147.

12. Soheli Ghose (December 2012), "An take a look at company Social responsibility in Indian and developing economies", international magazine of enterprise and management Invention, Vol. 1, problem - 1, Pp. 22 - 29.

13. Tejasweeta sunil Mundhe, (January 2013), "Indian ethos and corporate Social obligation by way of Indian groups", on line global interdisciplinary studies magazine, Vol. three, difficulty 1, Pp $118-123$.

14. Uvais. M, and Hafeefa Cholassere (March 2013), "corporate Social duty: Dimensions and troubles in India", international magazine of Engineering technology Invention, Vol. 2, trouble 3, Pp. 27 - 32.

15. Venugopal $\mathrm{R}$, corporate Social obligation and the insurance region, magazine of commercial enterprise approach 